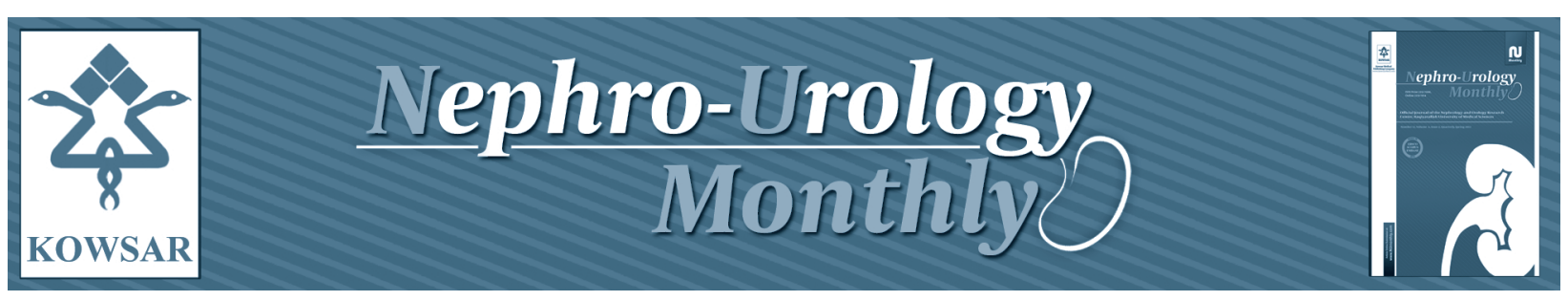

\title{
Direct Renin Inhibitor: Aliskiren in Chronic Kidney Disease
}

\author{
Yoshiyuki Morishita ${ }^{1^{*}}$, Eiji Kusano ${ }^{1}$ \\ ${ }^{1}$ Division of Nephrology, Department of Medicine, Jichi Medical University, Tochigi, Japan \\ * Corresponding author: Yoshiyuki Morishita, Division of Nephrology, Department of Medicine, Jichi Medical University, 3311-1, Yakushiji, Shimotsuke-city, \\ 329-0498, Tochigi, Japan. Tel.: + 81-285447346, Fax: +81-285444869, E-mail: ymori@jichi.ac.jp
}

\section{A B S T R A C T}

The renin-angiotensin-aldosterone system (RAAS) plays pivotal roles in the pathogenesis of chronic kidney disease (CKD) progression and its increased complications such as hypertension (HT) and cardiovascular diseases (CVD). Previous studies suggested that aliskiren a direct renin inhibitor, blocks RAAS and may be effective for the management of CKD and its complications. This review focuses on the effects of aliskiren on CKD.

Keywords: Kidney Failure, Chronic; Renin-Angiotensin System; Aliskiren; Blood Pressure; Cardiovascular Diseases

\section{Introduction}

Aliskiren is an orally active nonpeptide direct renin inhibitor, which acts by binding to the active site of renin (1). Aliskiren directly inhibits plasma renin activity (PRA), which acts at the initial and rate-limiting step in the renin-angiotensin-aldosterone system (RAAS), unlike the blockade of RAAS by angiotensin I-converting enzyme inhibitors (ACEIs) and angiotensin receptor blockers (ARBs) which cause a reactive rise in PRA (2).

RAAS plays pivotal roles in the pathogenesis of chronic kidney disease (CKD) progression (3). It has been reported that CKD is associated with increased risk of hypertension (HT) and cardiovascular diseases (CVD) (4-6). RAAS has been also shown to contribute to HT and CVD development in $\operatorname{CKD}(7,8)$. Many clinical trials have demonstrated that blockade of RAAS by ACEIs or ARBs could prevent the development and progression of CKD and its complications such as HT and CVD (9-14). Recent evidences suggest that aliskiren would be effective for CKD management and its complications such as HT and CVD (15-21). This review focuses on clinical studies that have demonstrated the effects of aliskiren on CKD.

\section{RAAS in CKD}

RAAS plays pivotal roles in the pathogenesis of CKD (3). Among RAAS components, angiotensin II (ATII) mainly causes vasoconstriction in the efferent glomerular arteries rather than the afferent ones, which induces glomerular hypertrophy (22). ATII also causes vasoconstriction at glomerular capillaries, which affects the glomerular filtration rate (23). ATII also contributes to increase connective tissue production and extracellular matrix deposi-

Article type: Review Article; Received: 01 Dec 2011, Revised: 12 Dec 2011, Accepted: 18 Dec 2011; DOI: 10.5812/numonthly.3679

-Implication for health policy/practice/research/medical education:

Aliskiren can block the renin-angiotensin-aldosterone system and have beneficial effects for the treatment of chronic kidney disease and its complications. However, the choice of aliskiren as well as its use has to be carefully determined considering the possible adverse effects and potential interactions with other drugs being used together.

Please cite this paper as:

Morishita Y, Kusano E. Direct Renin Inhibitor: Aliskiren in Chronic Kidney Disease.Nephro-Urol Mon.2013;5(1): 668-672. DOI: 10.5812/ numonthly.3679

Copyright (C) 2013, Kowsar Corp.; Published by Kowsar Corp.

This is an Open Access article distributed under the terms of the Creative Commons Attribution License (http://creativecommons.org/licenses/by/3.0), which permits unrestricted use, distribution, and reproduction in any medium, provided the original work is properly cited. 

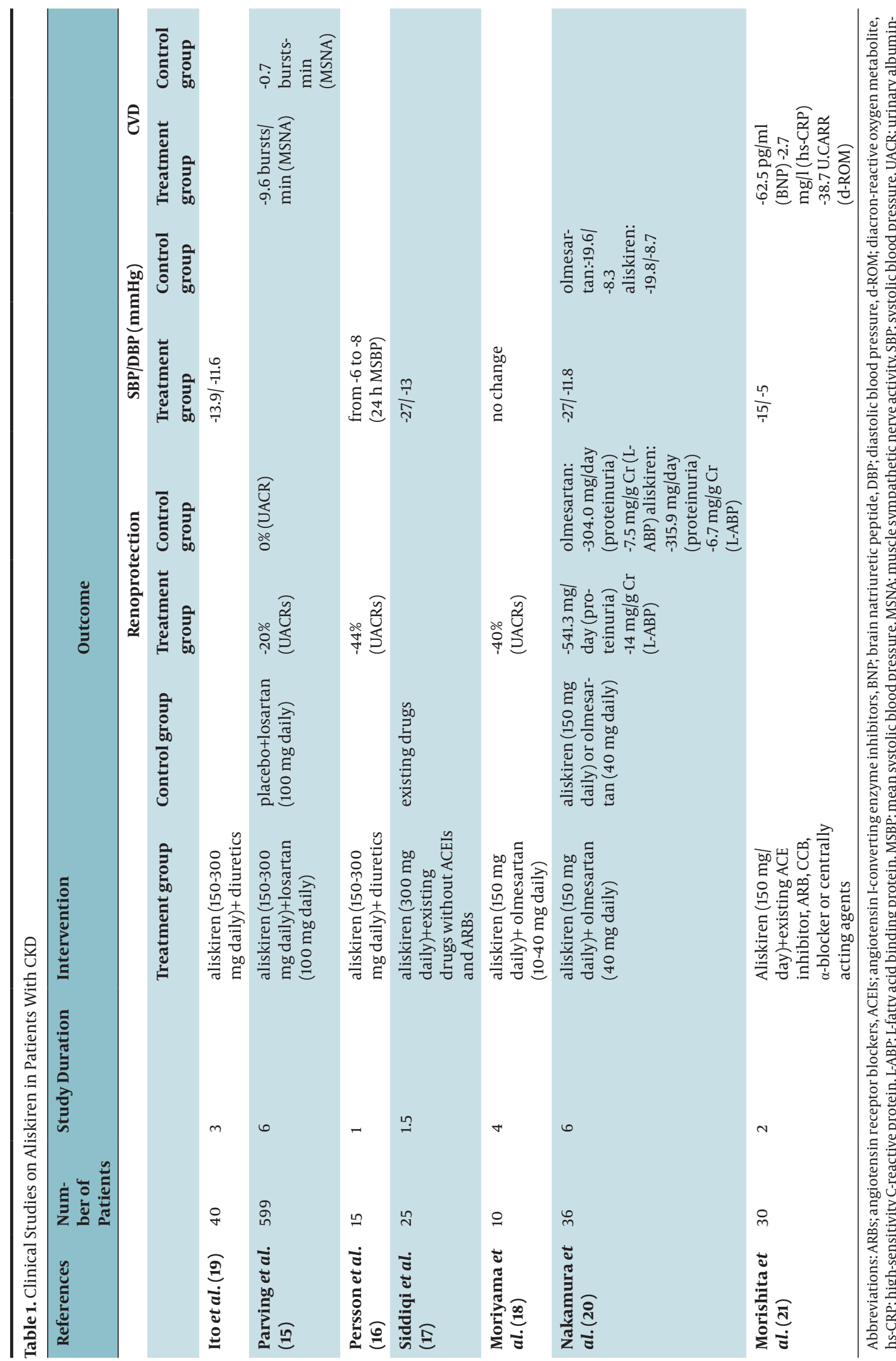

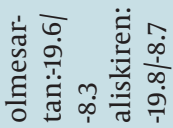

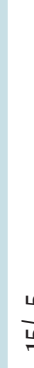

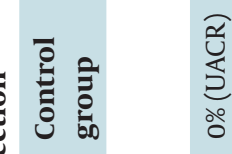
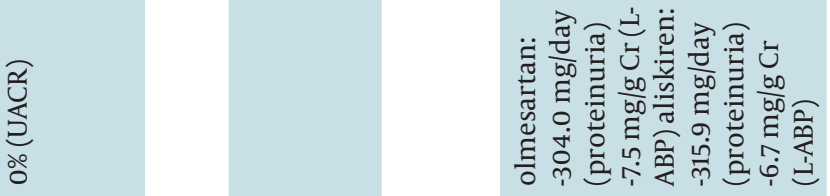

$\frac{n}{\frac{10}{10}}$

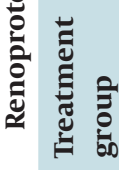

产造 辛

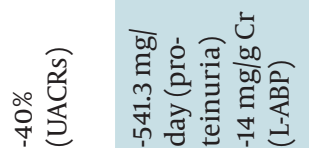
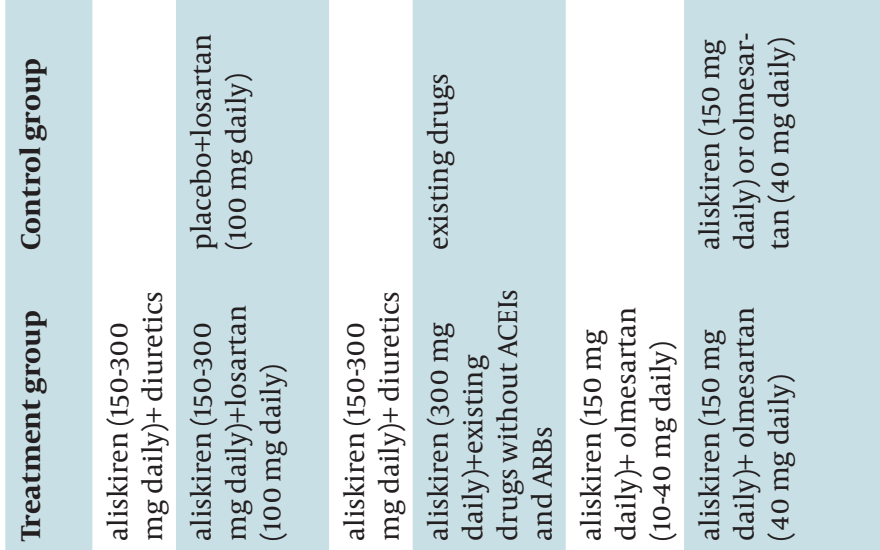
tion (24). RAAS also plays pivotal roles in the pathogenesis of HT and the development of $\operatorname{CVD}$ in $\operatorname{CKD}(7,8)$. The role of RASS in patients with hypertensive CKD was confirmed by the normalization of blood pressure (BP) following administration of an angiotensin antagonist, saralasin (25). Normally, volume overload and elevation of BP result in suppression of RAAS production. Since this feedback is often incomplete in CKD, patients with CKD often show HT and high or normal RAAS activity (7). Among RASS, ATII mainly contributes to the development of CVD. ATII has cellular effects that promote proliferation and hypertrophy of vascular smooth muscle cells and cardiac fibroblasts $(26,27)$. ATII also increases inflammatory mediators, which is an independent risk factor for CVD by directly increasing proinflammatory gene expression and activating oxidative stress, leading to progressive inflammation of the vascular endothelium (28-30).

\section{The Effects of Aliskiren on CKD}

Several clinical studies have demonstrated that aliskiren is effective on CKD ( Table 1 ). Ito et al. reported that aliskiren (150-300 mg daily) decreased systolic BP (SBP) and diastolic BP (DBP) by 13.9/11.6 \pm 11.6/9.7 (SBP/DBP, mean \pm SEM) at 8 weeks in patients with CKD (serum creatinine: 1.3-3.0 mg/dL in males, $1.2-3.0 \mathrm{mg} / \mathrm{dL}$ in females) (19). Persson et al. reported that aliskiren (300 mg daily) treatment added to furosemide reduced the mean $24 \mathrm{~h}$ SBP by 6-8 mmHg on days 7,14 , and 28 compared to baseline value in 15 patients with diabetic nephropathy (eGFR: $75.5 \mathrm{~mL} /$ $\min / 1.73 \mathrm{~m} 2$ ) (16). UACR also decreased progressively compared to baseline value, with a $17 \%$ reduction on days $2-4$, a $31 \%$ reduction on days $8-10$, and a maximum reduction of $44 \%$ at the end of the treatment (day 28) (16). These results strongly suggested that aliskiren has beneficial effects for renoprotection and BP control in CKD.

Parving et al. reported that treatment with aliskiren (150 mg daily for 3 months, followed by an increase in the dosage to $300 \mathrm{mg}$ daily for another 3 months) added to losartan (100 mg daily) reduced the mean urinary albumin-to-creatinine ratio (UACR) by $20 \%$; however, placebo did not reduce this ratio in 599 patients with hypertensive diabetic nephropathy (eGFR: $68.5 \pm 25.7 \mathrm{~mL} /$ $\mathrm{min} / 1.73 \mathrm{~m} 2$ (aliskiren group), $66.8 \pm 24.5 \mathrm{~mL} / \mathrm{min} / 1.73 \mathrm{~m} 2$ (placebo group) (15). Furthermore, only small differences in BP (SBP: 2 mmHg lower ( $\mathrm{P}=0.07)$ and DBP: $1 \mathrm{mmHg}$ lower $(\mathrm{P}=0.08)$ in the aliskiren group) were seen between the aliskiren group and the placebo group by the end of the study period (15). Moriyama et al. reported that aliskiren reduced the UACR in 10 patients with CKD (eGFR $30-90 \mathrm{~mL} / \mathrm{min}$ ) (18). In that study, aliskiren (150 mg daily) reduced the UACR by about $40 \%$ after 16 weeks from baseline when it was added to olmesartan (10-40 mg daily); however, it did not change eGFR and BP throughout the study period (18). These results suggest that aliskiren may have renoprotective effects regardless of BP lowering effects.
Siddiqi et al. reported that aliskiren (300 mg daily) decreased SBP and DBP, as well as sympathetic activity, in 10 patients with CKD (eGFR $57 \pm 22 \mathrm{ml} / \mathrm{min} / 1.73 \mathrm{~m} 2)$ (17). SBP/ DBP were reduced from $147 / 96 \pm 10 / 7$ to $120 / 83 \pm 8 / 7 \mathrm{mmHg}$ $(\mathrm{P}=0.01)(17)$. The sympathetic activity quantified by assessment of muscle sympathetic nerve activity (MSNA) was reduced from $36 \pm 8$ to $26 \pm 8$ bursts $/$ min $(P=0.01)$ (17). These results suggested that aliskiren could reduce sympathetic hyperactivity, which is often exhibited and contributed to the pathogenesis of HT and CVD in patients with CKD.

Nakamura et al. reported that the combination therapy of aliskiren (300 mg daily) and olmesartan (40 mg daily) caused greater reductions of SBP/DBP, proteinuria, and L-fatty acid binding protein (L-FABP), which is a marker of tubular injury, than monotherapy of olmesartan or aliskiren in nondiabetic patients with stage I or II of CKD over 6 months (20). In this study, the combination therapy of aliskiren and olmesartan reduced SBP/DBP from 157.3/89.3 $\pm 4.5 / 4.6$ to $130.3 / 77.5 \pm 2.3 / 2.7 \mathrm{mmHg}$, proteinuria from $1163.3 \pm 239.5 \mathrm{mg} /$ day to $622.0 \pm 355.2 .3 \mathrm{mg} /$ day, and L-ABP from $32.2 \pm 12.7 \mathrm{mg} / \mathrm{g}$ Cr to $18.2 \pm 6.2 \mathrm{mg} / \mathrm{g}$ Cr. In contrast, olmesartan monotherapy reduced SBP/ DBP from 155.8/89.5 \pm 4.9/4.6 to 136.2/81.2 \pm 5.0/3.5 mmHg, proteinuria from $1113.3 \pm 201.7 \mathrm{mg} /$ day to $809.3 \pm 239.2 \mathrm{mg} /$ day, and L-ABP from $33.1 \pm 10.5 \mathrm{mg} / \mathrm{g} \mathrm{Cr}$ to $25.6 \pm 7.0 \mathrm{mg} / \mathrm{g}$ $\mathrm{Cr}$, and aliskiren monotherapy reduced SBP/DBP from $157.6 / 90.2 \pm 5.9 / 4.0$ to $137.8 / 81.5 \pm 4.0 / 2.3 \mathrm{mmHg}$, proteinuria from $1149.2 \pm 264.9 \mathrm{mg} /$ day to $833.3 \pm 238.4 \mathrm{mg} /$ day, and L-ABP from $32.2 \pm 12.5 \mathrm{mg} / \mathrm{g}$ Cr to $25.5 \pm 9.9 \mathrm{mg} / \mathrm{g} \mathrm{Cr}$ (20). These results showed that the combination therapy of aliskiren and ARBs may be effective in patients with CKD.

Recently, we reported antihypertensive and potentially CVD-protective effects of aliskiren in patients with hypertensive CKD stage IV under hemodialysis (HD patients) (21). In this study, aliskiren (150 mg daily) significantly reduced SBP/DBP from 169.0/78.1 $\pm 20.1 / 12.0$ to $153.7 / 73.0 \pm$ 19.6/13.6 ( $P<0.05)$ after two months (21). RAAS was suppressed with aliskiren regimen after two months (PRA: $3.6 \pm 4.0$ to $1.0 \pm 1.5 \mathrm{ng} / \mathrm{mL} / \mathrm{hr}, \mathrm{P}=0.004$; angiotensin I (ATI): $1704.0 \pm 2580.9$ to $233.7 \pm 181.0 \mathrm{pg} / \mathrm{mL}, \mathrm{P}=0.009$; ATII: $70.2 \pm 121.5$ to $12.4 \pm 11.5 \mathrm{pg} / \mathrm{mL}, \mathrm{P}=0.022$ ) (21). Surrogate markers of CVD, such as brain natriuretic peptide (BNP), high-sensitivity C-reactive protein (hs-CRP), and an oxidative stress marker, diacron-reactive oxygen metabolite (dROM), were inhibited by aliskiren after two months (BNP: $362.5 \pm 262.1$ to $300.0 \pm 232.0 \mathrm{pg} / \mathrm{mL}, \mathrm{P}=0.043$; hs-CRP: 6.2 \pm 8.1 to $3.5 \pm 3.7 \mathrm{mg} / \mathrm{L}, \mathrm{P}=0.022$; $\mathrm{d}-\mathrm{ROM}: 367.0 \pm 89.8$ to 328.3 \pm 70.9 U.CARR, $P=0.022)(21)$. These results suggested that aliskiren is effective for BP control and may have CVD-protective effects in patients with hypertensive HD.

We also investigated the long-term effects, safety, and tolerability in those patients with hypertensive HD (under submission). Among 25 patients, 11 patients continued with aliskiren treatment (aliskiren group). Ten 
patients were withdrawn from aliskiren treatment after 3 to 8 months due to symptomatic hypotension; some of those patients had their BP controlled with antihypertensives such as calcium antagonists ( 5 patients), $\alpha$-blockers (1 patient), and $\beta$-blockers (1 patient) (aliskirenwithdrawn group). SBP/DBP decreased from $175 \pm 18 / 80 \pm$ $11 \mathrm{mmHg}$ at baseline to $155 \pm 19 / 76 \pm 9 \mathrm{mmHg}$ at month 20 in the aliskiren group. PRA, ATI, and ATII decreased from baseline to month $20(\mathrm{PRA}(\mathrm{ng} / \mathrm{mL} / \mathrm{h}): 2.3 \pm 2.6$ to $0.3 \pm 0.4$ ( $\mathrm{P}<0.05), \mathrm{ATI}(\mathrm{pg} / \mathrm{mL}) 909.1 \pm 902.5$ to $41.5 \pm 14.8(\mathrm{P}<0.05)$, ATII $(\mathrm{pg} / \mathrm{mL}): 41.5 \pm 45.8$ to $11.0 \pm 4.9 \mathrm{pg} / \mathrm{mL}(\mathrm{P}<0.05))$. BNP and d-ROM showed tendencies to decrease from baseline to month 20 (BNP (pg/mL): $248.9 \pm 197.2$ to $203.7 \pm 113.3$, d-ROM AT (U.CARR): $386.6 \pm 123.1$ to $305.6 \pm 67.4$ ). On the other hand, in the aliskiren-withdrawn group, SBP/DBP decreased from $171 \pm 13 / 80 \pm 14 \mathrm{mmHg}$ at baseline to $157 \pm$ $26 / 77 \pm 12 \mathrm{mmHg}$ at month 20. Although PRA, ATI, and ATII decreased at month 2 with aliskiren treatment (BaselineMonth 2 PRA $(\mathrm{ng} / \mathrm{mL} / \mathrm{h}): 3.3 \pm 2.9-0.9 \pm 0.7(\mathrm{P}<0.05)$, ATI $(\mathrm{pg} / \mathrm{mL}) 999.1 \pm 844.6-365.6 \pm 211.6(\mathrm{P}<0.05)$, ATII $(\mathrm{pg} /$ $\mathrm{mL}): 30.6 \pm 36.7-8.4 \pm 10.7(\mathrm{P}<0.05)$, Ald $(\mathrm{pg} / \mathrm{mL}): 97.2 \pm$ $57.5-79.3 \pm 35.7$ (NS)), they increased above the baseline level by withdrawal of aliskiren at month 20 (PRA (ng) $\mathrm{mL} / \mathrm{h}): 4.1 \pm 3.3$, ATI $(\mathrm{pg} / \mathrm{mL}) 801.0 \pm 1032.8$, ATII $(\mathrm{pg} / \mathrm{mL})$ $26.1 \pm 17.2$ ). In addition, d-ROM showed a tendency to decrease from baseline to month 2 followed by a further decrease at month 20 (Baseline-Month 2-Month 20: d-ROM (U.CARR): $402.3 \pm 69.0$ (Baseline) $-362.3 \pm 47.8$ (month 2 ) $336.3 \pm 58.5$ (month 20)); however, in one period, BNP (pg/ $\mathrm{mL}$ ) showed a tendency to decrease from baseline (425.3 \pm 207.3 (Baseline) $-409.5 \pm 287.8$ (month 2)), but it did not decrease from month 2 to month $20(412.9 \pm 287.8)$. These results suggested that long-term treatment with aliskiren provides effective BP lowering and inhibition of CVD surrogate markers which are sustained over 20 months in patients with hypertensive HD.

\section{Adverse Effects of Aliskiren on CKD}

Hyperkalemia, which is a frequent concern in patients with HD regardless of medication use, is the primary danger from RAAS-blocking medications. The blockade of RAAS leads to a decrease in aldosterone levels. Since aldosterone has a central role in the excretion of potassium, RAAS blockers can cause potassium retention. Several clinical trials of aliskiren in patients with CKD tracked potassium levels $(15,16,19,21)$. No significant trend for increased hyperkalemia by aliskiren in patients with CKD was observed in these trials $(15,16,19,21)$. Although careful and periodical monitoring of plasma potassium level is required, these results suggested that the risk of hyperkalemia by aliskiren in patients with CKD is small. One study reported that $15 \%$ of patients with CKD had adverse events that were suspected of being related to aliskiren. The most frequently reported adverse events were mild to moderate nasopharyngitis, back pain, and dizziness (5\% each) (19).
Several studies reported that mean trough plasma aliskiren concentrations increased with renal impairment $(19,31)$; however, an increase in exposure did not correlate with the severity of renal impairment (31). Moreover, renal clearance of aliskiren represents only a small fraction (0.1-1.0\%) (2). Although these data suggest that initial adjustment of the aliskiren dosage is unlikely to be required in patients with $\mathrm{CKD}$, careful observation of $\mathrm{BP}$ change is required for aliskiren treatment in patients with CKD because several studies have reported symptomatic hypotension with aliskiren in patients with CKD.

\section{Conclusion}

From previous studies, it is suggested that aliskiren has beneficial effects for renoprotection, the control of BP, and the prevention of CVD in patients with CKD. However, the choice of aliskiren as well as its use in the treatment of patients with CKD has to be carefully determined considering the possible adverse effects and potential interactions with other drugs being used together. Further high-quality studies that are well designed and have an adequate sample size are still needed to confirm the effects of aliskiren in patients with CKD.

\section{Acknowledgements}

None declared.

\section{Authors' Contribution}

Yoshiyuki Morishita wrote the paper, Eiji Kusano supervised the manuscript.

\section{Financial Disclosure}

There is no Financial disclosure.

\section{Funding/Support}

There is no funding/support.

\section{References}

1. Rodbard D. Statistical quality control and routine data processing for radioimmunoassays and immunoradiometric assays. Clin Chem. 1974;20(10):1255-70.

2. Nussberger J, Wuerzner G, Jensen C, Brunner HR. Angiotensin II suppression in humans by the orally active renin inhibitor Aliskiren (SPP100): comparison with enalapril. Hypertension. 2002;39(1):E1-8.

3. Ruster C, Wolf G. Renin-angiotensin-aldosterone system and progression of renal disease. J Am Soc Nephrol. 2006;17(11):2985-91.

4. Mann JF, Gerstein HC, Dulau-Florea I, Lonn E. Cardiovascular risk in patients with mild renal insufficiency. Kidney Int Suppl. 2003;84:S192-6

5. Agarwal R, Nissenson AR, Batlle D, Coyne DW, Trout JR, Warnock DG. Prevalence, treatment, and control of hypertension in chronic hemodialysis patients in the United States. Am J Med. 2003;115(4):291-7.

6. Herzog CA, Ma JZ, Collins AJ. Long-term survival of dialysis patients in the United States with prosthetic heart valves: should ACC/AHA practice guidelines on valve selection be modified? Circulation. 2002;105(11):1336-41. 
7. Blankestijn PJ, Ligtenberg G. Volume-independent mechanisms of hypertension in hemodialysis patients: clinical implications. Semin Dial. 2004;17(4):265-9.

8. Yerkey MW, Kernis SJ, Franklin BA, Sandberg KR, McCullough PA Renal dysfunction and acceleration of coronary disease. Heart. 2004;90(8):961-6.

9. Agarwal R, Sinha AD. Cardiovascular protection with antihypertensive drugs in dialysis patients: systematic review and metaanalysis. Hypertension. 2009;53(5):860-6.

10. Heerspink HJ, Ninomiya T, Zoungas S, de Zeeuw D, Grobbee DE, Jardine MJ, et al. Effect of lowering blood pressure on cardiovascular events and mortality in patients on dialysis: a systematic review and meta-analysis of randomised controlled trials. Lancet. 2009;373(9668):1009-15.

11. Jafar TH, Schmid CH, Landa M, Giatras I, Toto R, Remuzzi G, et al. Angiotensin-converting enzyme inhibitors and progression of nondiabetic renal disease. A meta-analysis of patient-level data. Ann Intern Med. 2001;135(2):73-78.

12. Schmieder RE, Klingbeil AU, Fleischmann EH, Veelken R, Delles C. Additional antiproteinuric effect of ultrahigh dose candesartan: a double-blind, randomized, prospective study. J Am Soc Nephrol. 2005;16(10):3038-45.

13. Hou FF, Zhang X, Zhang GH, Xie D, Chen PY, Zhang WR, et al. Efficacy and safety of benazepril for advanced chronic renal insufficiency. N Engl J Med. 2006;354(2):131-40.

14. Casas JP, Chua W, Loukogeorgakis S, Vallance P, Smeeth L, Hingorani $A D$, et al. Effect of inhibitors of the renin-angiotensin system and other antihypertensive drugs on renal outcomes: systematic review and meta-analysis. Lancet. 2005;366(9502):2026-33.

15. Parving HH, Persson F, Lewis JB, Lewis EJ, Hollenberg NK. Aliskiren combined with losartan in type 2 diabetes and nephropathy. N Engl J Med. 2008;358(23):2433-46.

16. Persson F, Rossing P, Schjoedt KJ, Juhl T, Tarnow L, Stehouwer CD et al. Time course of the antiproteinuric and antihypertensive effects of direct renin inhibition in type 2 diabetes. Kidney Int. 2008;73(12):1419-25.

17. Siddiqi L, Oey PL, Blankestijn PJ. Aliskiren reduces sympathetic nerve activity and blood pressure in chronic kidney disease patients. Nephrol Dial Transplant. 2011;26(9):2930-4

18. Moriyam T, Tsuruta Y, Kojima C, Itabashi M, Sugiura H, Takei T, et al. Beneficial effect of aliskiren combined with olmesartan in reducing urinary protein excretion in patients with chronic kidney disease. Int Urol Nephrol. 2012;44(3):841-845.
19. Ito S, Nakura N, Le Breton S, Keefe D. Efficacy and safety of aliskiren in Japanese hypertensive patients with renal dysfunction. Hypertens Res. 2010;33(1):62-6.

20. Nakamura T, Sato E, Amaha M, Kawagoe Y, Maeda S, Yamagishi SI Addition of aliskiren to olmesartan ameliorates tubular injury in chronic kidney disease patients partly by reducing proteinuria. J Renin Angiotensin Aldosterone Syst. 2012;13(1):122-127.

21. Morishita Y, Hanawa S, Chinda J, Iimura O, Tsunematsu S, Kusano E. Effects of aliskiren on blood pressure and the predictive biomarkers for cardiovascular disease in hemodialysis-dependent chronic kidney disease patients with hypertension. Hypertens Res. 2011;34(3):308-13.

22. Davalos M, Frega NS, Saker B, Leaf A. Effect of exogenous and endogenous angiotensin II in the isolated perfused rat kidney. Am Physio. 1978;235(6):F605-10.

23. Blantz RC, Gabbai FB. Effect of angiotensin II on glomerular hemodynamics and ultrafiltration coefficient. Kidney Int Suppl. 1987;20:S108-11.

24. Mezzano SA, Ruiz-Ortega M, Egido J. Angiotensin II and renal fibrosis. Hypertension. 2001:38(3 Pt 2):635-8.

25. Mimran A, Shaldon S, Barjon P, Mion C. The effect of an angiotensin antagonist (saralasin) on arterial pressure and plasma aldosterone in hemodialysis-resistant hypertensive patients. Clin Nephrol.1978;9(2):63-7.

26. Bell L, Madri JA. Influence of the angiotensin system on endothelial and smooth muscle cell migration. Am J Pathol. 1990;137(1):7 12.

27. Daemen MJ, Lombardi DM, Bosman FT, Schwartz SM. Angiotensin II induces smooth muscle cell proliferation in the normal and injured rat arterial wall. Circ Res. 1991;68(2):450-6.

28. Zoccali C, Benedetto FA, Mallamaci F, Tripepi G, Fermo I, Foca A, et al. Inflammation is associated with carotid atherosclerosis in dialysis patients. Creed Investigators. Cardiovascular Risk Extended Evaluation in Dialysis Patients. J Hypertens. 2000;18(9):1207-13

29. Landomesser U, Drexler H. oxidative stress, the renin-angiotensin system, and atherosclerosis. Europ Heart J. 2003;5:A3-A7.

30. Racki S, Zaputovic L, Mavric Z, Vujicic B, Dvornik S. C-reactive protein is a strong predictor of mortality in hemodialysis patients. Ren Fail. 2006;28(5):427-33.

31. Vaidyanathan S, Bigler H, Yeh C, Bizot MN, Dieterich HA, Howard D, et al. Pharmacokinetics of the oral direct renin inhibitor aliskiren alone and in combination with irbesartan in renal im pairment. Clin Pharmacokinet. 2007;46(8):661-75. 